\title{
Climate Change and Variability on Food Security of Rural Household: Central Highlands, Ethiopia
}

\author{
Argaw Tesfaye and Arragaw Alemayehu
}

\section{Contents}

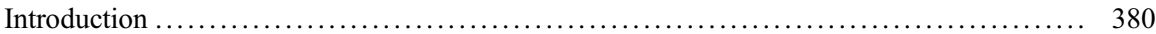

Impact of Climate Change and Variability on Food Security of Rural Household .......... 384

Variability and Trends in Rainfall and Temperature .......................... 384

Rural Household Perceptions of Climate Change and Variability and Their Impacts ... . . 389

Impacts of Climate Change and Variability on Food Security of Rural Households .... . . 390

Household Food Security Status ....................................... 391

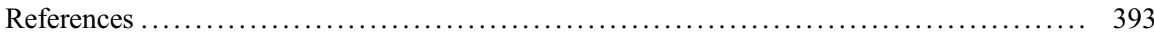

\section{Abstract}

This chapter analyzes the impact of climate change and variability on food security of rural households in the central highlands of Ethiopia taking Basona Werana district as a case study site. Data were obtained from 123 households selected using simple random sampling from three agro ecological zones. Key informant interviews and focus group discussion (FDG) were used to supplement the data obtained from household survey. The monthly rainfall and temperature data are for 56 points of $10 \times 10 \mathrm{~km}$ grids reconstructed from weather stations

This chapter was previously published non-open access with exclusive rights reserved by the Publisher. It has been changed retrospectively to open access under a CC BY 4.0 license and the copyright holder is "The Author(s)". For further details, please see the license information at the end of the chapter.

\footnotetext{
A. Tesfaye $(\square)$

Department of Geography and Environmental Studies, Mekdela Amba University, Mekane Selam, Ethiopia
A. Alemayehu
Department of Geography and Environmental Studies, Debre Berhan University, Debre Berhan, Ethiopia 
and meteorological satellite observations, which cover the period between 1983 and 2016. Standardized rainfall anomaly (SRA), linear regression (LR), and coefficient of variation (CV) are used to examine inter-annual and intra-annual variability of rainfall. Annual and seasonal rainfalls show decreasing trends over the period of observation. The decreasing trends in annual and March-May (Belg) rainfall totals exhibit statically significant decreasing trends at $p=0.05$ level. Kiremt (June-September) shows statically significant decreasing trends at $\mathrm{p}=0.1$ level. Mean annual maximum and minimum temperatures show statically significant increasing trends at $\mathrm{p}=0.05$ level. More than $80 \%$ of households perceived that the climate is changing and their livelihoods (crop and livestock production) are impacted. The district belongs to one of the most vulnerable areas to climate change and variability in the country where large proportions of households $(62 \%)$ are under different food insecurity classes. Results suggest that local level investigations are useful in developing context-specific climate change adaptation.

\section{Keywords}

Climate variability $\cdot$ Rainfall and temperature trends $\cdot$ Food security $\cdot$ Ethiopia

\section{Introduction}

Africa is already affected by climatic extremes such as floods, droughts, and windstorms, which are aggravated by climate change and variability. Ethiopia is one of the African countries which is most vulnerable to drought and floods (Belay et al. 2017). Climate change in the form of rising temperature, variable rainfall, droughts, and flooding affects agricultural production and threatens food security in low-income and agriculture-based economies (Mongi et al. 2010; Mesike and Esekhade 2014). Agriculture in Ethiopia is a major source of food and contributing sector to food security. It plays a key role in generating surplus capital to speed up the socioeconomic development of the country (Adem et al. 2018; Hagos et al. 2019).

Achieving food security and end hunger in the face of the ongoing impacts of climate change and variability is at the heart of the sustainable development goals. Climate change and variability are currently the biggest challenge affecting countries where rainfed agriculture is a means of livelihood (Asfaw et al. 2017).

The impact of climate change and variability on agricultural production increases economic and social challenges. Climate change affects agriculture in a different way. Climate extremes and changes in rainfall pattern are already influencing agricultural productivity. Increased tension in households, increased lethargy, poor school performance, and a range of other social ills are the major social impacts mostly reported (Akinseye et al. 2013).

Climate change and variability affect four dimensions of food security, namely, food availability, food accessibility, food utilization, and food system stability. The 
most direct impact on food security is through changes in food production. Shortterm variations are likely to be influenced by extreme weather events that disrupt production cycles (Alemu and Mengistu 2019). Climate change and variability affect food availability through its impacts on economic growth, income distribution, and agricultural demand markets, food prices, and supply chain (Schmidhuber and Tubiello 2007).

Historically, Ethiopia is well known for being prone to extreme events. The rainfall over Ethiopia exhibited high variability (Suryabhagavan 2017), and the country's economy has been affected by long-term changes in both rainfall amount and distribution where the country has witnessed frequent incidents of both excessive and deficient rainfalls (Zeleke et al. 2017). The most common drought periods known are 1957-1958, 1972-1974, 1984-1985, 2002-2003, and 2015-2016 (Markos 1997; Suryabhagavan 2017).

The central highland of Ethiopia, where the study area is located, is a droughtand famine-prone area. The people mainly derive their livelihood from subsistence agriculture, which is characterized by mixed farming system on fragmented land, over utilized land, and affected by erratic rainfall (Alemayehu and Bewket 2016a). Minor droughts are common every year due to climate variability. This brought an impact on the poor performance of the agricultural sector which affects rural livelihoods and food security (Asfaw et al. 2017). The central highland of Ethiopia is already food insecure, and large parts of the Basona Werana district are beneficiaries of the Productive Safety Nets Program (PSNP), which is the major food security program of the government (Alemayehu and Bewket 2017b).

Adaptation enables farmers to reduce vulnerability to adverse effect of climate change and variability. It helps rural communities cope with and adjust adverse consequences to climate change and variability (Deressa et al. 2010; IPCC 2014).

Degefa (2002), Frehiwot (2007), and Messay (2010) investigated the socioeconomic impacts of food security in different regions of Ethiopia. However, the impact of climate change and variability on food security is not addressed in their respective study areas.

Kahsay and Gebremicale (2018) investigated the impact of climate change on household food availability in Tigray region. The findings show that high prevalence of food insecurity has greater consequence among the female households. There are studies addressing the vulnerability context and impacts of climate change covering the central highlands of Ethiopia, which is also part of the present study (Bewket 2009; Alemayehu and Bewket 2016a, b, 2017a, b). This chapter links climate change and variability and food security in Basona Werana district by taking three agro ecological zones. This household level assessment is useful to identify and prioritize food insecure areas and contribute factors for adaptation planning.

Three kebeles (the lowest administrative level in the country) incorporating Kolla (lowland), Weyna Dega (midland), and Dega (highland) agro ecological zones were selected purposively to capture variations in agro ecology (Fig. 1). A total of 123 farmers were selected randomly (53 in Goshebado, 40 in Gudobert, and 30 in Kore Margfiya, respectively). Focus group discussions and key 


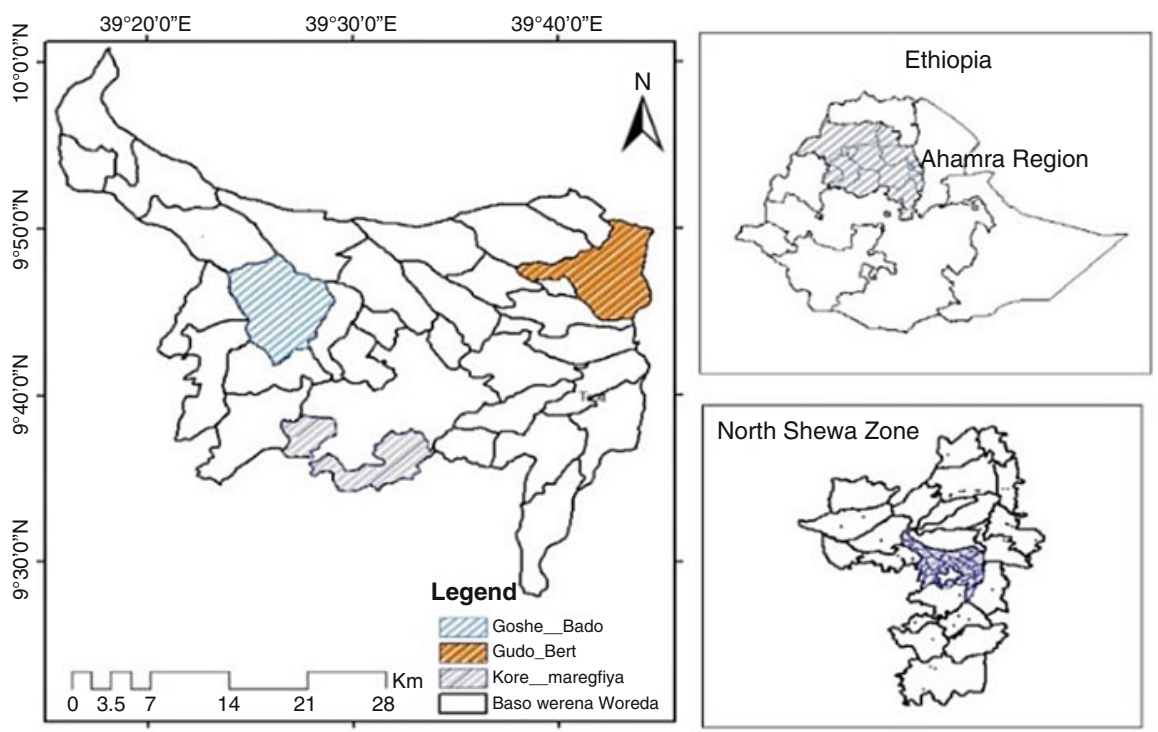

Fig. 1 Location of Basona Werana district, central highlands of Ethiopia

informant interviews were conductive to supplement the quantitative results from the household survey.

The monthly rainfall data used for this study are for 56 points (each representing areas of $10 \times 10 \mathrm{~km}$ ) for the period between 1983 and 2016 . The monthly maximum and minimum temperatures are for the same points and girds, but cover the period from 1981 to 2016. All were collected from the National Meteorological Agency of Ethiopia. Rainfall and temperature data were analyzed using coefficient of variation (CV), standardized rainfall anomalies (SRA), and linear regression (LR).

$\mathrm{CV}$ is expressed as a percentage and computed as

$$
\mathrm{CV}=(\sigma / \mu)
$$

where $\mathrm{CV}$ is the coefficient of variation

$\sigma=$ is the standard deviation

$\mu=$ is the mean rainfall

$\mathrm{CV}$ is used to classify the degree of variability of rainfall events. The different $\mathrm{CV}$ classes are less $(\mathrm{CV}<20 \%)$, moderate $(20 \%<\mathrm{CV}<30 \%)$, and high $(\mathrm{CV}>30 \%)$.

Standardized rainfall anomalies are calculated to examine the nature of the trends and determines of the dry and wet years in the period of observation as well as frequency and severity of droughts (Agnew and Chappel 1999; Bewket and Conway 2007).

As shown in Agnew and Chappel (1999), SRA is given as

$$
\mathrm{SRA}=(\mathrm{Pt}-\mathrm{Pm}) / \sigma
$$


where SRA $=$ standardized rainfall anomaly

$\mathrm{Pt}=$ annual rainfall in year $\mathrm{t}$

$\mathrm{Pm}=$ is long-term mean annual rainfall over a period of observation and

$\sigma=$ standard deviation of annual Rainfall over the period of observation

The different drought severity classes are calculated as shown in Agnew and Chappel (1999): extreme drought (SRA $<-1.65$ ), severe drought $(-1.28>$ SRA $>-1.65)$, moderate drought $(-0.84>$ SRA $>-1.28)$, and no drought (SRA $>-0.84$ ).

Linear regression was used to detect changes or trends in rainfall and temperatures. It is given as

$$
\mathrm{Y}=\mathrm{mx}+\mathrm{b}
$$

where $\mathrm{y}$ is dependent variable, $\mathrm{m}$ is the slope, $\mathrm{x}$ is independent variable, and $\mathrm{b}$ is the intercept.

Surface data were generated from 56 points of gridded monthly rainfall and temperature data $(10 \mathrm{~km} \times 10 \mathrm{~km})$ using simple kriging interpolation technique with ArcGIS 10.5.

Household Food Balance Model (HFBM) (sheet) was used to analyses the status of household food security of the sample households in order to classify the households as food secure and insecure (Mesay 2010; Derara and Degfa 2016)

$$
\begin{aligned}
\mathrm{NGA}= & (\mathrm{GPi}+\mathrm{GBi}+\mathrm{GRi}+\mathrm{GPSi}) \\
& -(\mathrm{HLi}+\mathrm{GUi}+\mathrm{GSi}+\mathrm{GVi}+\mathrm{NSi})
\end{aligned}
$$

where

$\mathrm{NGA}=$ Net grain available (quintal/household/year); a quintal $=100 \mathrm{Kgs}$

$\mathrm{GPi}=$ Total grain production (quintal/household/year)

$\mathrm{GBi}=$ Total grain bought (quintal/household/year)

$\mathrm{GSi}=$ Total grain obtained through gift or remittance (quintal/household/year)

$\mathrm{GPSi}=$ Total grain obtained from previous year (stock/year/household)

$\mathrm{HLi}=$ Post-harvest losses due to grain pests, disasters, thievery (quintal/household/ year)

$\mathrm{GUi}=$ Quantity of grain reserved for seed (quintal/household/year)

$\mathrm{MOi}=$ Amount of marketed output (quintal/household/year)

$\mathrm{GVi}=$ Grain given to others within a year (quintal/household/year)

$\mathrm{NSi}=$ Grain planned to be left by a household for next season (quintal/household/

year)

Descriptive statistical methods such as frequencies, means, and percentages were used to summarize the information on food security issues and climate change perceptions, impacts, and adaptation strategies. Chi-square test is used to test the statistical significance of variations across AEZs. 


\section{Impact of Climate Change and Variability on Food Security of Rural Household}

\section{Variability and Trends in Rainfall and Temperature}

As shown in Table 1, the average annual rainfall of the area for the study period is $1013 \mathrm{~mm}$, with standard deviation of $125 \mathrm{~mm}$ and CV of $12 \%$. Annual rainfall varies from $784 \mathrm{~mm}$ (2011) to $1227.2 \mathrm{~mm}$ (1985). The results of trend analysis of annual and seasonal rainfall are presented in Table 1. Accordingly, annual and seasonal rainfalls show statistically significant decreasing trends except Bega (OctoberFebruary) rainfall where there is no clear trend. Annual rainfall shows statistically significant decreasing trend $63.58 \mathrm{~mm} /$ decade at $\mathrm{p}=0.05$ level. Belg rainfall also showed statistically significant decreasing trend at $\mathrm{p}=0.05$ level. Result supports previous studies by Williams et al. (2012) and Kebede (2013) who reported declining trends in Belg rainfall. Kiremt rainfall has shown statistically significant decline of $23.2 \mathrm{~mm} /$ decade. Elsewhere in Ethiopia, Kiremt rains support the main cropping season locally known as Meher at $\mathrm{p}=0.1$ level. The declining trends of Kiremt rainfall will aggravate the food security challenges in the area.

The coefficient of variation revealed that rainfall in the area has low inter-annual variability (12\%) (Table 1). June to Kiremt rainfall has large contribution to annual rainfall (72\%), with CV of 13\%. Belg and Bega seasons have high rainfall variability each having CV of $42.6 \%$ and $56.8 \%$, respectively. Belg rainfall contributed $17 \%$ of annual rainfall.

Rainfall distribution was highly concentrated in the few months of the year (July to September). July and August are the wettest months. July has the highest monthly rainfall $(295 \mathrm{~mm})$ which contributes $30 \%$ of annual rainfall. August has $287.5 \mathrm{~mm}$ rainfall and contributes about $29 \%$. November and December are the driest months, having $11 \mathrm{~mm}$ of rainfall each (Fig. 2).

Analysis of the standard rainfall anomaly is used to show the intensity and frequency of drought and inter-annual variation at various spatiotemporal scales. The rainfall pattern showed a characteristic that a dry year is followed by another 2 or 3 dry years and vis-à-vis for the wet years.

Table 1 Trends of annual and seasonal rainfall

\begin{tabular}{l|l|l|l|l|l|l|l|l}
\hline & Mean & LR & $\begin{array}{l}\text { Wettest } \\
\text { year }\end{array}$ & $\begin{array}{l}\text { Amount } \\
\text { rainfall } \\
(\mathrm{mm})\end{array}$ & $\begin{array}{l}\text { Driest } \\
\text { year }\end{array}$ & $\begin{array}{l}\text { Amount } \\
\text { rain fall } \\
(\mathrm{mm})\end{array}$ & SD & CV \\
\hline Annual & 1013 & $-63.58^{\mathrm{a}}$ & 1985 & 1227.2 & 2011 & 783.8 & 124.4 & 12.3 \\
\hline Kirmet & 733.8 & $-23.2^{\mathrm{b}}$ & 1997 & 918.9 & 1987 & 485.3 & 98.6 & 13.4 \\
\hline Belg & 182.4 & $-24.8^{\mathrm{a}}$ & 1987 & 437.1 & 1998 & 58 & 77.7 & 42.6 \\
\hline Bega & 87.5 & -11.6 & 1997 & 237.2 & 2011 & 13.3 & 49.7 & 56.8 \\
\hline
\end{tabular}

$\mathrm{LR}=$ linear trends (mm 10/year)

${ }^{\text {a }}$ Significant at 0.05 level

${ }^{\mathrm{b}}$ Significant at 0.1 level 


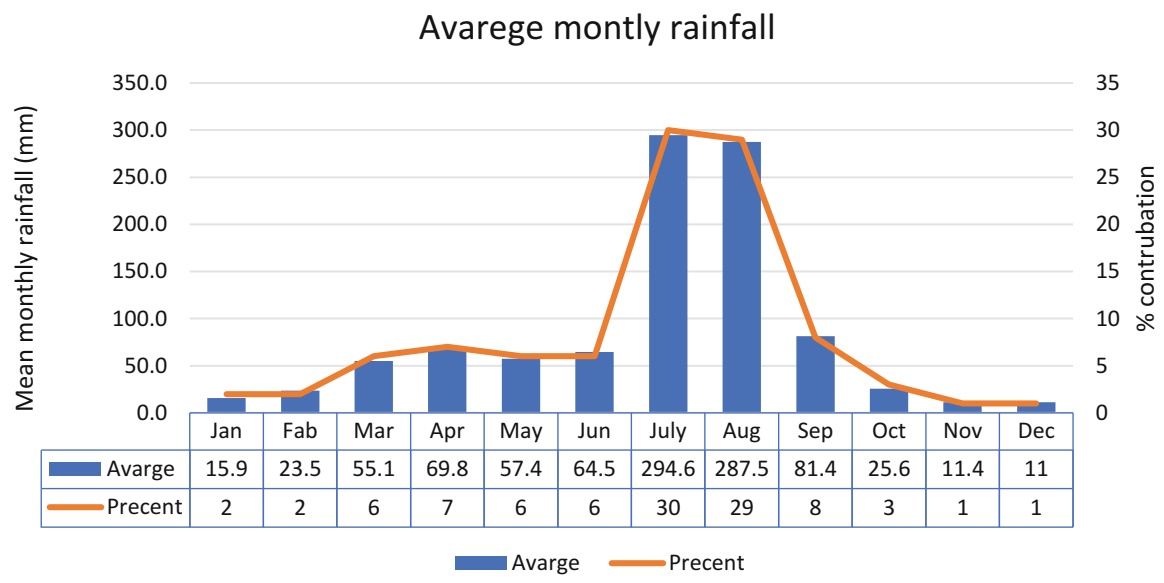

Fig. 2 Monthly rainfall (in $\mathrm{mm}$ ) and contribution to the annual total (in \%)

After the 1984 drought, annual rainfall showed some recovery, but with considerable internal variations. Extreme drought $(<-1.65)$ is observed during the years $1984,2008,2009,2011$, and 2015. Severe drought $(-1.28$ to -1.65$)$ is observed for the years 1989, 1995, and 2005 (Fig. 3). The years 2006 and 2007 show positive anomalies. The year 2006 was a major flood year in the country, which caused loss of life and property in different parts of the country particularly in Dire Dawa and South Omo (Alemayehu and Bewket 2017a). The proportions of negative and positive anomalies account for $61 \%$ and $39 \%$ of the total observations, respectively. The 1980 s and 1990 s are wet compared with the 2000 s. Close to $23 \%$ of observations fall under different drought categories.

At show in Fig. 3, negative and positive Kiremt rainfall anomalies account for $52 \%$ and $48 \%$ of observations for the period 1983-2016, respectively. Extreme drought was observed in the years 1984 and 1987 and severity drought in 2008 and 2011. Belg rainfall positive anomalies account for $42 \%$ of total observation. The extreme drought is observed in 1992, 1997, 1998, 2008, 2009, 2013, and 2014. Belg rainfall anomalies are relatively more positive in the driest decade of the 1980s than the others. Generally, the findings repeat the earlier works of Bewket and Conway (2007), Rosell (2011), Ayalew et al. (2012), and Alemayehu and Bewket (2017a) who reported a similar finding for the central highlands of Ethiopia.

Figure 4 shows the spatial distribution of annual and seasonal rainfall distribution and trends over the period of analysis. Large proportion of the district (42\%) receives annual rainfall of between 829 and $886 \mathrm{~mm}$. About $35 \%$ of the area in the southern part of the district receives rainfall of between 77 and $829 \mathrm{~mm}$. Close to $33 \%$ of the area in the in the northwestern part receives rainfall of between 886 and $955 \mathrm{~mm}$. Most of the grid points of annual rainfall trend fall within -0.84 and -0.04 ranges. Result coincides with a previous study by Alemayehu and Bewket (2017a) on local scale variability, and trends of rainfall and temperature in the central highlands of Ethiopia that reported most of the grid points fall within -0.1 and -0.7 range which 

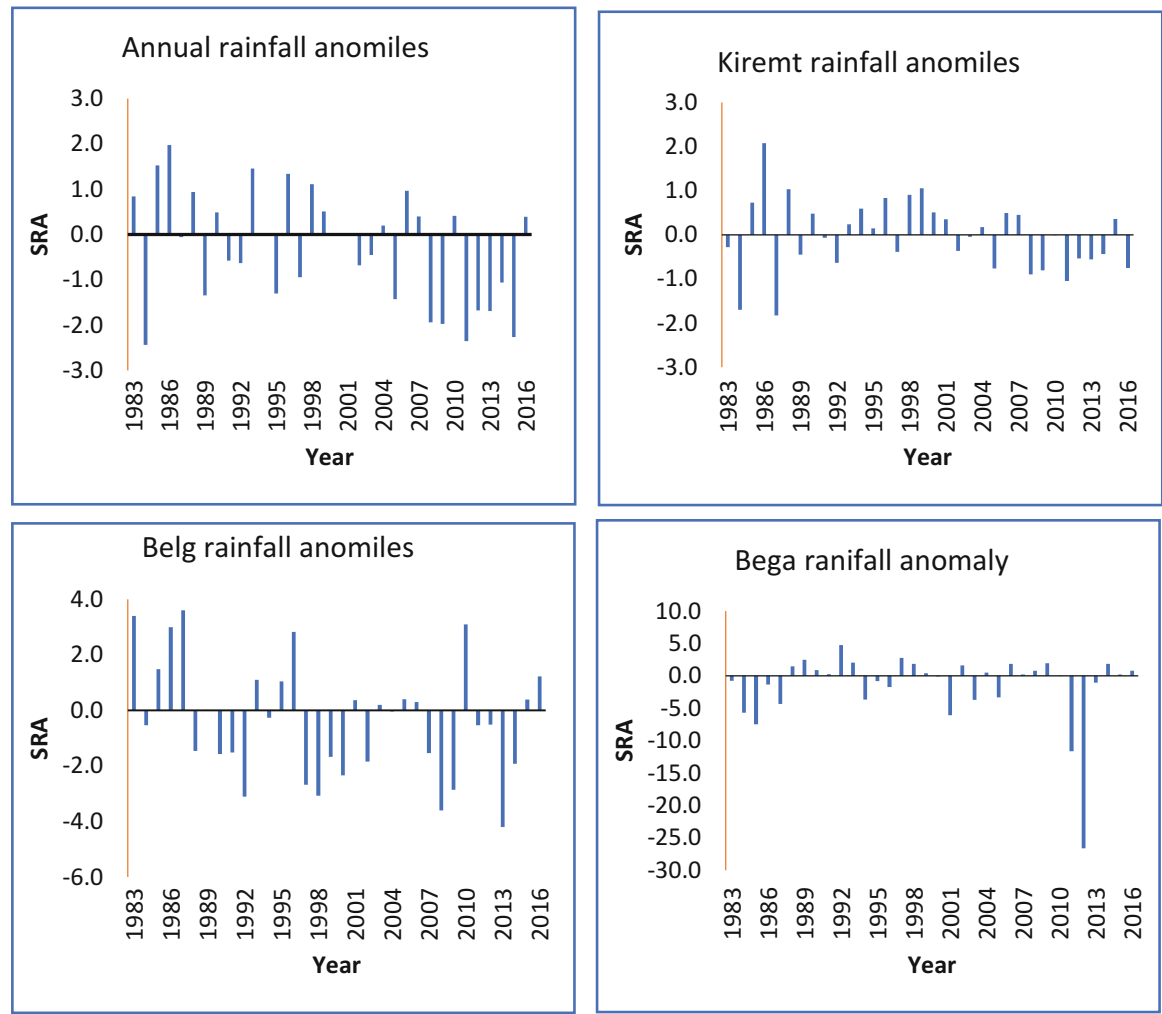

Fig. 3 Temporal variations in the annual and seasonal rainfall anomalies

exhibit strong negative trend of annual rainfall. The implication is that drying trends in the district have adverse consequences on the already poor performance of the agricultural sector in the area. Drying trend of Belg rainfall $(-0.4$ to -0.02$)$ in the area is observed. The implication is on the Belg season production, which is important for household level food security in the locality (Alemayehu and Bewket 2017a). In the case of Kiremt rainfall ( -3 to 2$)$ trends in the upper part of the district is observed. In the middle part of the district (0 to 2), positive trends were observed, whereas the lower part of the district negative trends $(-3$ to -1$)$.

The mean annual temperature is $13.2{ }^{\circ} \mathrm{C}$. The lowest and highest mean annual temperatures are experienced in 1999 and 2009, respectively. The lowest temperature is $12.1{ }^{\circ} \mathrm{C}$ and highest temperature $14.5^{\circ} \mathrm{C}$ with a standard deviation of 0.46 and coefficient variation of 0.03 . The lowest temperature is $-2.1{ }^{\circ} \mathrm{C}$ (December) with a standard deviation of 0.8 and coefficient variation of 0.12 . The highest temperature is $24.4{ }^{\circ} \mathrm{C}$ (February) with a standard deviation of 0.42 and coefficient variation of 0.02 . The mean annual minimum temperature ranges from $4.83{ }^{\circ} \mathrm{C}(2000)$ to $-2.1^{\circ}$ $\mathrm{C}$ (1998), and the long-term mean is $6.3^{\circ} \mathrm{C}$. The mean annual maximum temperature ranges from $23.4{ }^{\circ} \mathrm{C}(2009)$ to $15.8^{\circ} \mathrm{C}(1994)$, and the long-term mean is $19.7{ }^{\circ} \mathrm{C}$. 
a

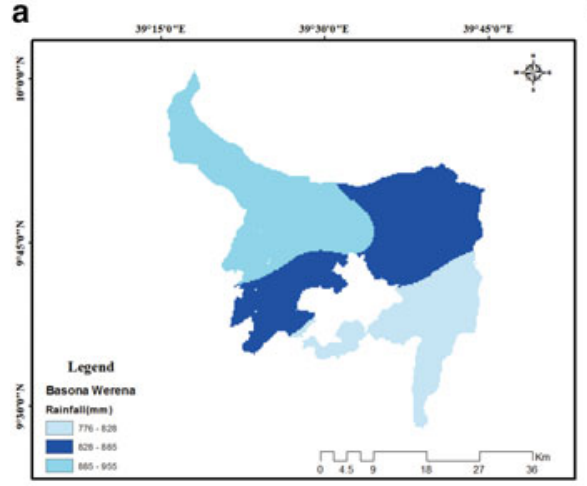

c

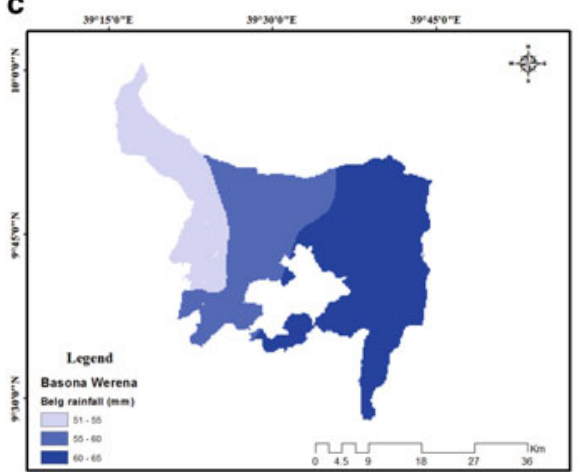

e

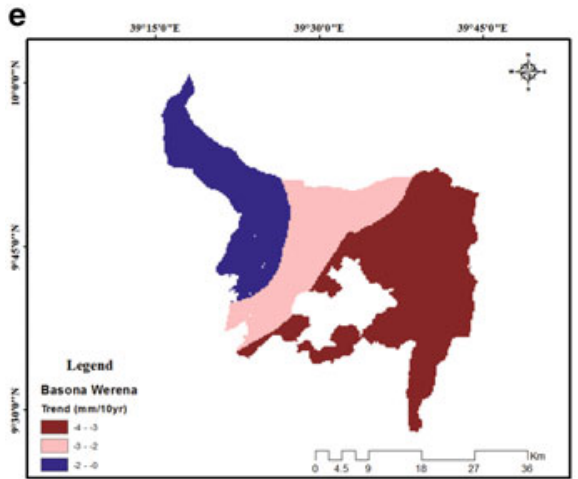

b

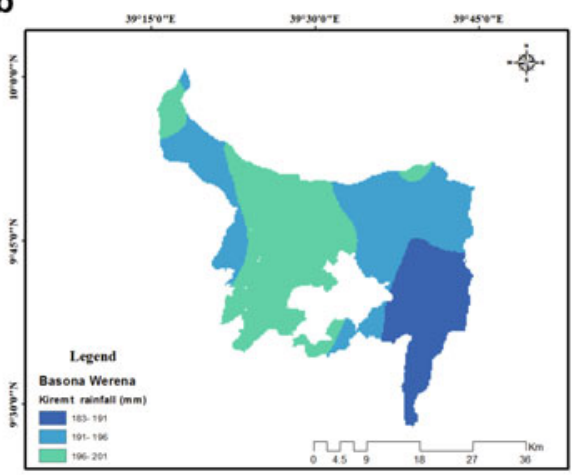

d

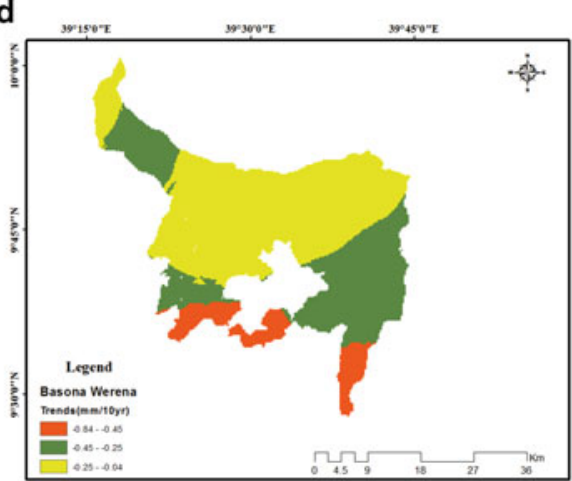

f

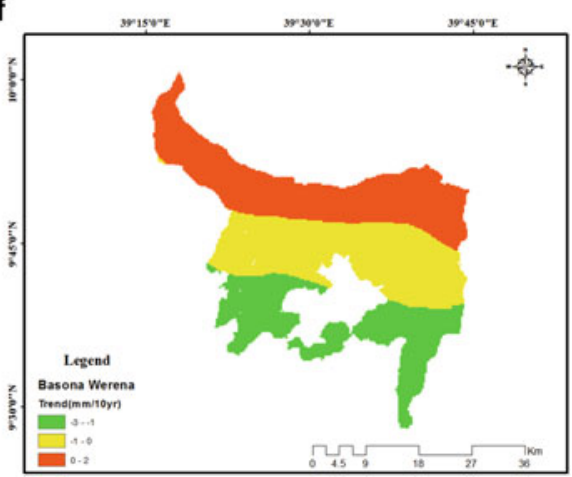

Fig. 4 Spatial distribution of annual rainfall and seasonal rainfall (A, B, C) and annual rainfall and seasonal trends (D, E, F)

The mean annual maximum temperature shows warming trends for the period 1983-2016. The warming trend in the maximum temperature $\left(0.2^{\circ} \mathrm{C} /\right.$ decade $)$ is statistically significant at $\mathrm{p}=0.05$ level.

As show in Table 2, Bega and Belg season's maximum temperature experienced statistically significant increasing trends at $\mathrm{p}=0.05$ and 0.1 levels, respectively. 
Table 2 Annual and seasonal trends in the mean maximum and minimum temperature

\begin{tabular}{l|l|l|l|l|l|l|l|l}
\hline & \multicolumn{7}{|c}{ Mean maximum and minimum temperature ${ }^{\circ} \mathrm{C}$} \\
\cline { 2 - 10 } & Annual & LT & Kiremt & LT & Bleg & LT & Bega & LT \\
\hline $\begin{array}{l}\text { Maximum } \\
\text { temperature }\end{array}$ & 19.7 & $0.02^{\mathrm{a}}$ & 19.36 & -0.1 & 20.96 & $0.03^{\mathrm{b}}$ & 19.6 & $0.28^{\mathrm{a}}$ \\
\hline $\begin{array}{l}\text { Minimum } \\
\text { Temperature }\end{array}$ & 6.29 & $0.42^{\mathrm{a}} \mathrm{C}$ & 8 & -0.015 & 7.27 & $0.0114^{\mathrm{b}}$ & 3.61 & 0.013 \\
\hline
\end{tabular}

$\mathrm{LR}=$ linear trends $\left(0^{\mathrm{c}} / 10\right.$ year $)$

${ }^{\text {a}}$ Significant at 0.05 level

${ }^{\mathrm{b}}$ Significant at 0.1 level
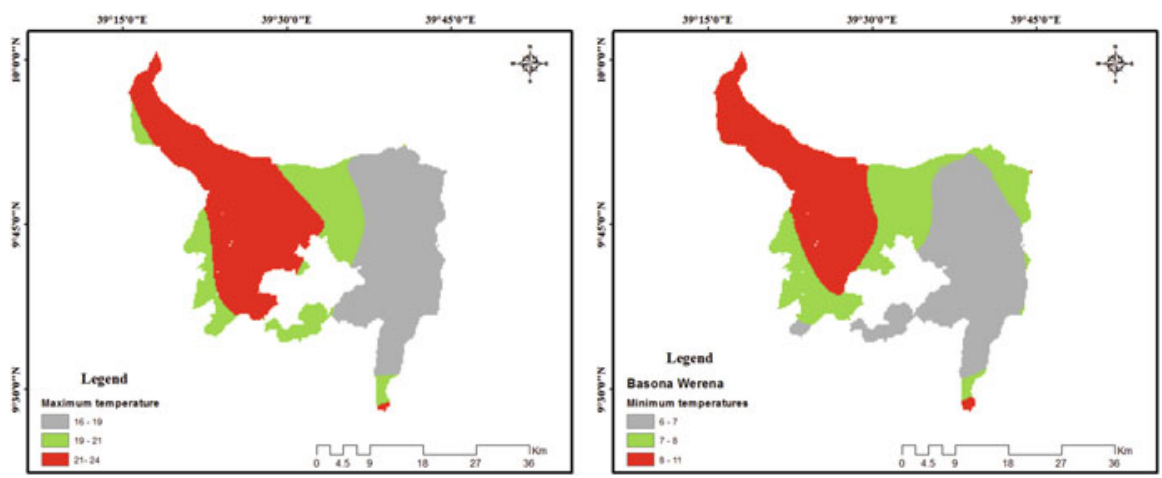

Fig. 5 Spatial distribution of mean maximum (left) and minimum temperatures (right)

Kiremt season's maximum temperature experienced statistically nonsignificant decreasing trend.

The annual minimum temperature shows positive trend. Minimum temperature has experienced statistically significant increasing trend at $\mathrm{p}=0.01$ level. Kiremt minimum temperature shows declining trend at $\mathrm{p}=0.05$ level. The trends for the Bega and Belg minimum temperatures are similar with the maximum temperature; statistically significant increasing trends at $\mathrm{p}=0.05$ and 0.1 levels, respectively, are observed (Table 2). Earlier studies by Conway et al. (2004), NMA (2007), Jury and Funk (2012), Tesso et al. (2012), and Taye and Zewdu (2012) also reported a warming trend of the minimum temperature in their respective study areas and periods.

Figure 5 shows the spatial distribution of mean maximum and minimum temperatures. Both mean maximum and minimum temperatures are higher in the northwestern part of the district and decrease in the southeast. The maximum temperature for northern parts of district ranges from $22{ }^{\circ} \mathrm{C}$ to $24^{\circ} \mathrm{C}$ and the lowest southeast 10 $20{ }^{\circ} \mathrm{C}$, whereas the minimum temperature of the district is lowest in the southeast ranging from $6^{\circ} \mathrm{C}$ to $7^{\circ} \mathrm{C}$ in the study period. 


\title{
Rural Household Perceptions of Climate Change and Variability and Their Impacts
}

Table 3 shows that about $88 \%$ of farmers perceived that the climate has been changed. Close to $94 \%$ of households in the Kolla agro ecological zone perceived that they have been experiencing climate change and variability. This is followed by Dega agro ecological zone where $93 \%$ of households perceived climate change and variability.

\begin{abstract}
A key informant from Dega agro ecological zone explains: in the last three decades, Belg rains are highly variable and shows declining trends in the surrounding. Belg rains now are non-existent become history to the area. The worst case is that Kiremt rainfall is insufficient due to increasing water demand. Kiremt rainfall starts late and ends early. Coupled with other environmental changes like land degradation and soil erosion, current climate variability challenges food security; not capable of producing enough food for family members.
\end{abstract}

Results from FGDs also confirmed that rainfall is declining from time to time while temperature is getting warmer. About $67 \%$ of households in all agro ecological zones perceived that temperature shows warming trend, while $20 \%$ of households perceived that temperature shows declining trends in their locality. Close to $13 \%$ of households report no observable change of temperature. Statistically significant mean difference was observed in terms of perception of temperature across agro ecological zones at $\mathrm{p}=0.1$ level.

Regarding changes in rainfall patterns, close to $59 \%$ of households reported that rainfall shows decreasing trends. The other $35 \%$ of households observed changes in the timing of rainfall. Farmers in the Kolla agro ecological zone reported declining trends in rainfall ( $73 \%$ of households). About $53 \%$ and $52 \%$ of households from

Table 3 Rural household perceptions of climate change and variability and their impacts

\begin{tabular}{|c|c|c|c|c|c|}
\hline \multirow[b]{2}{*}{ Climate change/variability } & \multicolumn{3}{|c|}{ Agro ecological zone } & \multirow[b]{2}{*}{ Mean } & \multirow[b]{2}{*}{$X^{2}$} \\
\hline & Dega & Kolla & Weyna Dega & & \\
\hline Yes & 93 & 94 & 70 & 88 & \multirow[t]{2}{*}{$11.819^{\circ}$} \\
\hline No & 8 & 6 & 30 & 12 & \\
\hline \multicolumn{6}{|l|}{ Temperature pattern } \\
\hline Increased & 65 & 71 & 64 & 67 & \multirow[t]{3}{*}{$8.323^{\mathrm{b}}$} \\
\hline Decreased & 27 & 20 & 11 & 20 & \\
\hline No observable change & 8 & 9 & 25 & 13 & \\
\hline \multicolumn{6}{|l|}{ Rainfall perceived } \\
\hline Decrease in rainfall amount & 52 & 73 & 53 & 59 & \multirow[t]{3}{*}{5.111} \\
\hline Change in timing of rain & 43 & 24 & 37 & 35 & \\
\hline No change in rainfall & 5 & 3 & 11 & 6 & \\
\hline
\end{tabular}

${ }^{\text {a }}$ Significant at 0.05 level

${ }^{\mathrm{b}}$ Significant at 0.1 level 
Weyena Dega and Dega agro ecological zone perceived declining of rainfall trends, respectively.

Rural households' perception of changes in rainfall and temperature corroborates the results of metrological data analysis. They perceived reduced rainfall and warming temperatures. Analysis of climate data revealed declining trends of annual and seasonal rainfalls. Similarly, warming of the minimum and maximum temperatures is observed from analysis of climate data.

Regarding the cause of climate change, about $39 \%$ of households reported human interventions caused climate change. Close to $11 \%$ of households in the three agro ecological zones reported natural factors caused climate change. About $40 \%$ and $36 \%$ of households in the Dega and Kolla agro ecological zones attributed climate change with religious factors. Statistically significant mean difference was observed in terms of perceived causes of climate change across agro ecological zones at $p=0.01$ level. Results of FGD participants and KIIs reported the effect of deforestation for different purposes is the main cause of climate change.

\section{Impacts of Climate Change and Variability on Food Security of Rural Households}

As show in Table 4, majority of the households (88\%) reported changes in rainfall pattern as the main challenge of their livelihoods. The onset and offset periods of rainfall are unpredictable and affect sowing and harvesting periods. Prevalence of pest and diseases was mentioned by $82 \%$ of the households. The effect of flood is reported by $48 \%$ of the households. Snow as a challenge to food security is reported by $65 \%$ of the households. For example, months from October to December are the coldest months in the area. Thus, matured crops are more likely to be affected by frost. Drought has several negative consequences in the area; it causes extensive damages to crops and loss of agricultural production. Close to $67 \%$ of the households replied that drought was the major climate-related factor challenging agricultural productivity in the area (Table 4).

Table 4 Impact of climate change and variability on livelihood

\begin{tabular}{l|l|l|l|l|l}
\hline & \multicolumn{2}{|l|}{ Agro ecological zone } & \multirow{2}{*}{} & \multirow{2}{*}{ Major climate elements } \\
\cline { 2 - 6 } & Dega & Kolla & Weyna Dega & Mean & $\mathrm{X}^{2}$ \\
\hline Temperature increased & 79 & 96 & 87 & 87 & $6.906^{\mathrm{a}}$ \\
\hline Change in rainfall & 79 & 97 & 87 & 88 & 4.758 \\
\hline Drought & 58 & 73 & 67 & 66 & $9.883^{\mathrm{b}}$ \\
\hline Flood & 58 & 34 & 50 & 48 & 2.189 \\
\hline Snow & 60 & 71 & 63 & 65 & 1.361 \\
\hline Pests and diseases & 88 & 76 & 83 & 82 & $10.182^{\mathrm{b}}$ \\
\hline
\end{tabular}

${ }^{a}$ Significant at 0.05 level

${ }^{\mathrm{b}}$ Significant 0.01 level 
Table 5 Correlation between climate change and variability and food security

\begin{tabular}{l|l|l|l|l|l|l}
\hline \multicolumn{2}{l|}{} & $\begin{array}{l}\text { Temperature } \\
\text { change }\end{array}$ & $\begin{array}{l}\text { Rainfall } \\
\text { variability }\end{array}$ & Flood & Drought & Frost \\
\hline \multirow{2}{*}{$\begin{array}{l}\text { Food } \\
\text { security }\end{array}$} & $\begin{array}{l}\text { Pearson } \\
\text { Correlation }\end{array}$ & -0.182 & -0.157 & 0.231 & -0.150 & -0.174 \\
\cline { 2 - 7 } & Sig.(2-tailed) & 0.044 & 0.083 & 0.010 & 0.098 & 0.055 \\
\cline { 2 - 7 } & $\mathrm{N}$ & 123 & 123 & 123 & 123 & 123 \\
\hline
\end{tabular}

Statistically significant mean difference was observed in terms of perceived impacts of climate change and variability on livelihoods across agro ecological zones.

Bivariate correlation was used to analyze the association between food security and climate change and variability over the last two to three decades. The food security status of a household is determined by the rate of temperature and rainfall changes, occurrence of flood, drought, and frost which have adverse negative impacts on crop and animal productivity thereby affecting the food security status of rural households (Table 5).

Results of the bivariate correlation showed that food security has negative correlation with temperature change at $\mathrm{p}=0.05$ level. Similarly, rainfall variability and occurrence of drought and frost have negative correlations at $\mathrm{p}=0.1$ levels. Food security has positive correlation with occurrence of flood at $\mathrm{p}=0.05$ level.

\section{Household Food Security Status}

HFBM was used to determine household food security status. The result of the HFBM reveals that $62 \%$ of households are food insecure and failed to satisfy their daily minimum requirement recommended for their households $(2100 \mathrm{Kcal} / \mathrm{adul}$. equ), while $38 \%$ of the households are food secured. At agro ecological zone level, food insecurity is highest in the Dega (67\% of the households) followed by Kolla ( $60 \%$ of the households), whereas majority of food secured households are found in Weyna Dega agro ecological zone ( $43 \%$ of the households). This is because of the fact that topographic and climate factors are conducive for crop production in the Weyna Dega agro ecological zone compared to others (Alemayehu and Bewket 2016b).

There are different constraints that hinder agricultural productivity and then induce food insecurity. As shown in Table 6, almost all households (99\%) replied that poor soil fertility was the main factor reducing productivity thereby causing food insecurity. This is followed by climate variability ( $97 \%$ of the households). About $95 \%$ and $93 \%$ of the households reflected that farmland shortage and low non-farm income are among the major causes for food insecurity, respectively. Farmers felt that insect, pests, and weeds caused food insecurity. Statistically significant variation in terms of agro ecological zone is observed among the causes of food insecurity at $\mathrm{P}=0.01$ level. 
Table 6 Cause of food insecurity

\begin{tabular}{|c|c|c|c|c|c|}
\hline \multirow[b]{2}{*}{ Cause of food insecurity } & \multicolumn{3}{|c|}{ Agro ecological zone } & \multirow[b]{2}{*}{ Mean } & \multirow[b]{2}{*}{$X^{2}$} \\
\hline & Dega & Kolla & $\begin{array}{l}\text { Weyna } \\
\text { Dega }\end{array}$ & & \\
\hline Traditional farm practices & 98 & 98 & 96 & 97 & 1.230 \\
\hline Land fragmentation & 100 & 83 & 63 & 82 & $16.962^{\mathrm{a}}$ \\
\hline Shortage of labor & 95 & 76 & 90 & 87 & $7.641^{\mathrm{b}}$ \\
\hline Poor soil fertility & 100 & 96 & 100 & 99 & 2.685 \\
\hline $\begin{array}{l}\text { Climate variability(rainfall and } \\
\text { temperature }\end{array}$ & 100 & 90 & 100 & 97 & $6.884^{\mathrm{b}}$ \\
\hline Prevalence of animal disease & 70 & 88 & 67 & 75 & $5.175^{\mathrm{c}}$ \\
\hline Deforestation & 97 & 77 & 73 & 82 & $9.111^{\mathrm{b}}$ \\
\hline Farm land shortage & 100 & 98 & 88 & 95 & $8.948^{\mathrm{b}}$ \\
\hline Drought & 85 & 57 & 60 & 67 & $9.065^{\mathrm{b}}$ \\
\hline Poor access credit & 88 & 66 & 37 & 64 & $6.701^{\mathrm{c}}$ \\
\hline Low non in farm income & 89 & 97 & 93 & 93 & 3.613 \\
\hline Shortage of grazing land & 88 & 72 & 90 & 83 & $5.719^{b}$ \\
\hline Low access market & 57 & 80 & 40 & 59 & $11.936^{\mathrm{a}}$ \\
\hline
\end{tabular}

${ }^{\mathrm{a}}$ Significant 0.01 level

${ }^{\mathrm{b}}$ Significant at 0.05 level

${ }^{\mathrm{c}}$ Significant at 0.1 level

Shortage of labor, climate variability, deforestation, farm land shortage, and shortage of grazing land as cause of food insecurity show statistical difference across agro ecological zone at $\mathrm{p}=0.05$ level. While lack of credit access and prevalence of animal diseases show significant difference at $p=0.1$ level. The office of Agriculture and Natural Resources of the Amhara Regional State reported that about 15$26 \%$ of post-harvest production loss was observed. Coupled with the already low production, the post-harvest loss further affected household food security through diminishing the amount of available food reserve.

This result supported a previous study by Tilaye (2004) in Amhara Region of Ethiopia which identified different factors that cause food insecurity by deteriorating the food production capacity of households. These included drought, soil erosion, land fragmentation, population and pressure poor farming technology, and high labor west age as major causes of food insecurity.

In response, households used different coping and adaptation strategies to mitigate the adverse effects of climate change and variability on food security. About nine types of adaptation measures are identified. These are soil and water conservation, changing planting date, use of fertilizer, planting tree, animal fattening, livelihood diversification, irrigation, improved seed, and crop diversification. The majority of farmers (99\%) used soil and water conservation practices as adaptation to the impact climate change variability on food security. This is followed by changing crop planting dates ( $98 \%$ of households). While the least strategies are 
irrigation (21\%) and animal fattening (59\%). Similarly, changing consumption pattern and sell of livestock product (butter, milk, and cheese) are the dominant coping strategies used by $88 \%$ and $83 \%$ of the households, respectively. While migration and purchase of food by credit are the least coping strategies used by $21 \%$ and $37 \%$ of the households, respectively.

\section{References}

Adem M, Tadele E, Mossie H, Ayenalem M (2018) Income diversification and food security situation in Ethiopia: a review study. Food Sci Technol 4:1-17

Agnew C, Chappel A (1999) Drought in the Sahel. Geo J 48:299-311

Akinseye F, Ajayi V, Oladitan T (2013) Assessing the impacts of climate variability on crop yield over Sudano-Sahelian zone in Nigeria. Int J Agric Sci 1(7):91-98

Alemayehu A, Bewket W (2016a) Local climate variability and crop production in the central highlands of Ethiopia. Environ Dev 19:36-48

Alemayehu A, Bewket W (2016b) Vulnerability of smallholder farmers' to climate change and variability in the central highlands of Ethiopia. Ethiopian Journal of the Social Sciences and Humanities 12(2): 1-24

Alemayehu A, Bewket W (2017a) Smallholder farmers' coping and adaptation strategies to climate change and variability in the central highlands of Ethiopia. Local Environ 22(7):825-839

Alemayehu A, Bewket W (2017b) Determinants of smallholder farmers' choice of coping and adaptation strategies to climate change and variability in the central highlands of Ethiopia. Environ Dev 24:77-85

Alemayehu A, Bewket W (2017c) Local spatiotemporal variability and trends in rainfall and temperature in the central highlands of Ethiopia. Geogr Ann Ser B 99(2):85-101

Alemu T, Mengistu A (2019) Impacts of climate change on food security and its adaptation and mitigation options in Ethiopia: a review. In: International conference on impact of El Niño on biodiversity, agriculture, and food security, 23-24 February 2017 Haramaya University, Ethiopia, p 75

Asfaw A, Simane B, Hassen A, Bantider A (2017) Determinants of non-farm livelihood diversification: evidence from rain fed-dependent smallholder farmers in northcentral Ethiopia (Woleka sub-basin). Dev Stud Res 4(1):22-36

Ayalew D, Tesfaye K, Mamo G, Yitaferu B, Bayu W (2012) Variability of rainfall and its current trend in Amhara region, Ethiopia. Afr J Agric Res 7(10):1475-1486

Belay A, Recha J, Woldeamanuel T, Morton (2017) Smallholder farmers' adaptation to climate change and determinants of their adaptation decisions in the Central Rift Valley of Ethiopia. Agric Food Secur 6(1):24

Bewket W (2009) Rainfall variability and crop production in Ethiopia: case study in the Amhara region. In: Ege S, Aspen H, Teferra B, Bekele S (eds) Proceedings of the 16th international conference of Ethiopian studies. Norwegian University of Science and Technology, Trondheim, Norway

Bewket W, Conway D (2007) A note on the temporal and spatial variability of rainfall in the drought-prone Amhara region of Ethiopia. Int J Climatol 27:1467-1477

Conway D, Mould C, Bewket W (2004) Over one century of rainfall and temperature observations in Addis Ababa. Ethiop Int J Climatol 24:77-91

Degefa T (2002) Household seasonal food insecurity in Oromiya Zone, Ethiopia: S.S research report series no 26, OSSREA, A.A 
Derara F, Degfa T (2016) Household food security situation in Central Oromia, Ethiopia: a case study from Becho Wereda in Southwest Shewa Zone. Glob J Hum Soc Sci Res 16 (2): $1-16$

Deressa T, Hassan R, Tekie A, Mahmud Y, Ringler C (2010) Analyzing the determinants of farmers choice of adaptation methods and perceptions of climate change in the Nile Basin of Ethiopia. Sustainable solutions for ending hunger and poverty. IFPRI discussion paper 00798. IFPRI, Washington DC

Frehiwot F (2007) Food insecurity and its determinants in rural households in Amhara Region. Msc thesis, Department of Economics, Faculty of Business and Economics, School of Graduate Studies, Addis Ababa University, Ethiopia

Hagos A, Dibaba R, Bekele A, Alemu D (2019) Determinants of Market Participation among Smallholder Mango Producers in Assosa Zone of Benishangul Gumuz Region in Ethiopia. Int J Fruit Sci 20(3): 323-349

Intergovernmental Panel on Climate Change (IPCC) (2014) Climate change: the scientific basis: contribution of working group I to the third assessment report. Cambridge University Press, Cambridge

Jury R, Funk C (2012) Climatic trends over Ethiopia: regional signals and drivers. Int J Climatol. http://onlinelibrary.wiley.com/doi/10.1002/joc.3560

Kahsay S, Gebremicale D (2018) Impact of climate variability on food availability in Tigray, Ethiopia. J Agric Food Secur 7(6):1-9

Kebede G (2013) Spatial and temporal uncertainty of rainfall in arid and semi-arid areas of Ethiopia. Sci Technol Arts Res J 2(4):106-113

Markos E (1997) Demographic responses to ecological degradation and food insecurity: drought prone areas in northern Ethiopia. Amsterdam. Thesis Publishers Ph.D. dissertation

Mesay M (2010) Food security attainment role of urban agriculture: a case study from Adama Town, Central Ethiopia. J Sustain Dev Afr 12(3):223-250

Mesike S, Esekhade T (2014) Rainfall variability and rubber production in Nigeria. Afr J Environ Sci Technol 8(1):54-57

Mongi H, Majule E, Lyimo G (2010) Vulnerability and adaptation of rain fed agriculture to climate change and variability in semi-arid Tanzania. Afr J Environ Sci Technol 4(6)

National Meteorological Agency (NMA) (2007) Climate change: National Adaptation Program of Action (NAPA) of Ethiopia. Ministry of Water Resources, Addis Ababa

Rosell S (2011) Regional perspective on rainfall change and variability in the central highlands of Ethiopia, 1978-2007. Appl Geogr 31:329-338

Schmidhuber J, Tubiello F (2007) Global food security under climate change. Proc Natl Acad Sci 104(50):19703-19708

Suryabhagavan K (2017) GIS-based climate variability and drought characterization in Ethiopia over three decades. Weather Clim Extrem 15:11-23

Taye M, Zewdu F (2012) Spatio-temporal variability and trend of rainfall and temperature in Western Amhara, Ethiopia: a GIS approach. Glo Adv Res J Geogr Reg Plann 1(4):65-82

Tesso G, Emana B, Ketema M (2012) A time series analysis of climate variability and its impacts on food production in North Shewa zone in Ethiopia. Afr Crop Sci J 20(2):261-274

Tilaye T (2004) Food insecurity: extent, determinants and household copping mechanisms in Gera Keya Woreda, Amhara region. MA thesis, Addis Ababa University

Williams P, Funk C, Michaelsen J, Rauscher S, Robertson I, Wils T, Koprowski M, Eshetu Z, Loader N (2012) Recent summer precipitation trends in the greater horn of Africa and the emerging role of Indian Ocean Sea surface temperature. Clim Dyn 39:2307-2328. https://doi. org/10.1007/s00382-011-1222-y

Zeleke T, Giorgi F, Diro GT, Zaitchik B (2017) Trend and periodicity of drought over Ethiopia. Int J Climatol 37:4733-4748 
Open Access This chapter is licensed under the terms of the Creative Commons Attribution 4.0 International License (http://creativecommons.org/licenses/by/4.0/), which permits use, sharing, adaptation, distribution and reproduction in any medium or format, as long as you give appropriate credit to the original author(s) and the source, provide a link to the Creative Commons license and indicate if changes were made.

The images or other third party material in this chapter are included in the chapter's Creative Commons license, unless indicated otherwise in a credit line to the material. If material is not included in the chapter's Creative Commons license and your intended use is not permitted by statutory regulation or exceeds the permitted use, you will need to obtain permission directly from the copyright holder.

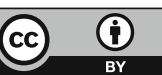

